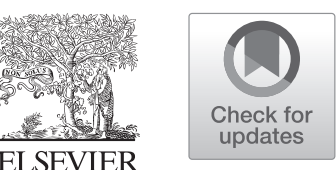

\title{
Barriers to Registration in the National Donor Registry in Nations Using the Opt-In System: A Review of the Literature
}

\author{
P.E. Vorstius Kruijff ${ }^{a, \star}$, M. Witjes ${ }^{b, c}$, N.E. Jansen ${ }^{c}$, and R. Slappendel ${ }^{d}$ \\ ${ }^{a}$ Department of Quality and Safety, Amphia Teaching Hospital, Breda, The Netherlands; ' Department of Intensive Care Medicine, \\ Radboud University Medical Center, Nijmegen, The Netherlands; 'Department of Organ Procurement, Dutch Transplant Foundation, \\ Leiden, The Netherlands; 'Department of Anesthesia, University of Antwerp, Antwerpen, Belgium
}

\begin{abstract}
Background. To increase the number of postmortem organ and tissue donors, donor registries (DRs) have been introduced. The aim of this review was to understand why people in nations with an Opt-in system, who are for or against donation after death, do not register in the DR. Knowing these barriers will help in developing policies to increase the registration rate in the DR.

Methods. For this review, 2 authors independently assessed the eligibility of the identified studies from 2000 to 2015 in the Pubmed- Medline database. Included were observational and interventional studies concerned with reported barriers to residents joining the national DR in Denmark, The Netherlands, and the United Kingdom.

Results. We included 15 relevant articles for the review. The main barriers to signing the DR in nations using the Opt-in system were: religion; medical mistrust, anxiety, and affective emotions; lack of information; concern about insufficient time to mourn, and that the funeral may be delayed and the deceased not look presentable; physical integrity; ignorance about how to register in the DR; own benefit; and social status.

Conclusions. The outcome suggests that the main barriers to enrolling in the DR are based on people's doubts about their own ability to perform the registration and cope with the consequences, knowledge, outcome expectations, and concerns about what others will think of them for agreeing to donation. However, not all barriers are easily modifiable, owing to their association with affect or emotions.
\end{abstract}

$\mathbf{I}^{\mathrm{N}}$ MANY nations the demand for donor organs for patients on the waiting list for organ transplantation exceeds the supply. To increase the number of postmortem organ and tissue donors, a large number of Western European nations introduced the Opt-out or Opt-in decisionmaking systems.

According to the Opt-out system, all residents are donors, unless they register objection. Within the Opt-in system, residents have to declare their donor preferences (by free choice). For that latter purpose, the donor registry (DR) records an individual decision to be a donor after death. Examples of European nations that use the Opt-in system with a national DR are Denmark (DK), the Netherlands (NL), and the United Kingdom (UK; except Wales).

The Dutch Organ and Tissue Act has been in force since 1998, including a DR [1,2]. All Dutch citizens, within 1 year after reaching the age of 18 years, receive an organ donor registration form from the government, on which they can indicate their organ donation preferences. The DR provides 4 options to register: 1) consent, specified per organ and tissue; 2) objection; 3) decision by next of kin; and 4) decision by a specific person. At the time this Act was introduced in 1998 , only $36 \%$ of the inhabitants administered their choice in the DR [3]. Despite several initiatives, at the time of writing $\sim 41 \%$ of the Dutch population $\geq 18$ years of

*Address correspondence to P.E. Vorstius Kruijff, Department of Quality and Safety, Amphia Teaching Hospital, PO Box 90157, 4800 RL Breda, The Netherlands. E-mail: evorstiuskruijff@ amphia.nl

$0041-1345 / 18$

https://doi.org/10.1016/j.transproceed.2018.01.054 
age registered their donor preferences. This means that $59 \%$ did not take the step to register [2].

When a potential donor is not registered in the DR, the next of kin have to make a decision about donation. In these emotional and often acute situations, most next of kin object to organ $(68 \%)$ or tissue $(84 \%)$ donation [4]. Therefore, knowledge of a potential donor's consent or their expressed views and wishes is a key issue.

This high percentage of objection by next of kin seems to be in contrast to surveys suggesting that more than one-half of Dutch citizens advocate organ and tissue donation. When the topic is discussed in a hospital with family members, more than one-half are willing to donate organs from a deceased family member $[5,6]$. In addition, when the DR is not decisive and next of kin object to donation, approximately one-third regret their decision afterward [7].

Registration in the DR gives people the opportunity to express their donor wishes. This gives clarity and certainty at the time of death to all family members concerned. It is therefore important to understand why people, who are for or against donation after death, do not sign up for the DR. To identify barriers that influence registration in the DR, a review of the literature was made. Knowing these barriers will help to develop policies in order to increase the number of registrations in the DR.

\section{METHODS}

Western European nations with Opt-in systems similar that in NL are DK and UK (except Wales) [8]. These nations are the most comparable regarding demography, the legal consent system, and a national DR with similar options (Table 1).

\section{Data Sources and Searches}

We performed a literature search from 2000 to 2015 in the PubmedMedline database with the use of specific search terms (Table 2).

\section{Study Selection}

To understand factors influencing enrollment in the DR, we introduced and developed the concept of a "time line" (Fig 1). In step 1, the person is assumed to be familiar with the existence of the subject of organ and tissue donation, including the DR. In step 2, the person is receptive to the subject of donation. In step 3, which we call the "preparation phase," the person is orientating and contemplating to make a decision about registration into the national DR. The following step 4, which we call the "action phase," is when the person has to enter his/her preferences regarding organ and tissue donation in the DR.

To categorize the reviewed articles, we applied the time line to sign the DR (Fig 1). Only original research papers were included that showed elements of behavior that apparently influence or are associated with steps 3 and 4 .

We included full-text publications written in English, observational or interventional studies, if they complied with reported behavioral factors associated with inhabitants joining the national DR in DK, NL, or UK.

We excluded articles not describing behavioral research concerning enrollment in the DR.

\section{Search Terms}

We developed a Boolean search strategy and used the PatientIntervention-Comparison-Outcome method.

\section{Validity Assessment and Data Abstraction}

Two authors (E.V.K. and M.W.) screened the obtained articles and abstracts for eligibility. Results were compared, and in case of any disagreement reconciliation was made through discussion with a 3rd author (N.J.). First, we excluded articles associated with steps 1 and 2 as defined in the time line (Fig 1) on the basis of title, abstract, or full text. Second, when studies seemed to meet eligibility criteria (steps 3 and 4 of the time line or when the information was insufficient to exclude them), we obtained the full-text articles. References that were identified from full-text articles were also collected and screened.

\section{RESULTS}

The database search produced a list of 4,853 relevant citations. Of these we excluded 4,234 citations because they concerned other nations than DK, UK, and NL (Fig 2). Potentially relevant citations in the title and abstracts were screened (619), and after exclusion (593) we identified 26 potential articles and 4 articles from the reference lists from these papers (snowball method). After screening full-text articles, we excluded 15 articles that did not meet the inclusion criteria, and we finally included 15 relevant articles for the review.

Table 1. National Donor Registries

\begin{tabular}{|c|c|c|c|}
\hline Nation & Operation Level & $\begin{array}{l}\text { Minimum } \\
\text { Age }\end{array}$ & Additional Details \\
\hline United Kingdom & National (www.organdonation.nhs.uk) & None & Welsh*: Opt in/deemed consent/opt out. Next of kin are entitled to consent. \\
\hline The Netherlands & National (www.donorregister.nl) & 12 & $\begin{array}{l}\text { The Donor Registry provides } 4 \text { options to register: 1) permission; } \\
\text { 2) objection; 3) next of kin decides; and } \\
\text { 4) a specific person decides. Next of kin are entitled to consent. }\end{array}$ \\
\hline Denmark & National (www.sundhed.dk) & 18 & $\begin{array}{l}\text { Registration includes "yes," "no," and "unsure." } \\
\text { Individuals can also add with next of kin approval to } \\
\text { their registration. Next of kin are entitled to consent. }\end{array}$ \\
\hline
\end{tabular}

*Welsh legislation: The law in Wales has changed to bring in a soft "opt-out" system for consent to organ donation. People living in Wales now have 3 choices: 1) If you want to be a donor, you can either register to be a donor (opt in) on the NHS Organ Donor Registry or do nothing; if you do nothing, you are regarded as having no objection to donating your organs, and this is called "deemed consent"; 2) if you do not want to be a donor, you can register not to be a donor (opt out) on the NHS Organ Donor Registry; and 3) you can also appoint a representative to make the decision for you after your death. By removing your name from the NHS Organ Donor Registry, you put yourself in the "do nothing" or "deemed consent" category. 
Table 2. Data Source

\begin{tabular}{ll}
\hline \multicolumn{1}{c}{ Databases and hand search } & Pubmed/Medline and snowball \\
\hline Inclusion criteria & Whether or not observational or interventional studies complied with reported influencing factors \\
& associated with residents joining the national donor registry (Fig 1, steps 3 and 4) addressed \\
& to nations Denmark, the Netherlands, and United Kingdom. \\
Type & National or regional donor registry for deceased organ and tissue donation \\
Search terms & PICO: \\
& Population = "donor registry OR tissue and organ procurement" \\
& AND \\
& Intervention = "behavior OR attitude OR altruism OR motivation OR accept* \\
& OR belief* OR attitude* OR willing OR choice OR social responsible* \\
& AND \\
& Comparison = Netherlands OR Dutch OR Holland OR United Kingdom \\
& OR British OR England OR Denmark OR Danish \\
& AND \\
Outcome \\
explicit consent (opt in) & Denmark, The Netherlands, and the United Kingdom \\
system with a national register & \\
Language of articles & English \\
Date of publication & All lay and informed people \\
Ethnicity and age & Factors (behavioral barriers/facilitators) to sign/join the national donor registry \\
Subject & Observational or interventional study \\
Setting &
\end{tabular}

\section{Study Characteristics}

We summarized the included studies (Table 2). All of the studies were conducted in NL (47\%) and UK (53\%). No relevant articles were found from DK. Most of the research focused on students (NL $47 \%$ vs UK $40 \%$ ), the general public (UK 13\%), or ethnic minorities in a geographically defined region or country.

The studies identified were mainly of 2 types; observational (survey) and interventional (education). Some of the studies were based on social cognitive [R6,R9-R14] and noncognitive $[\mathrm{R} 8, \mathrm{R} 15]$ theories or studies in which no behavioral theory were described [R1-R5,R7].

Research based on social cognitive theories was mainly performed in NL (NL 33\% vs UK 13\%) and 13\% noncognitive theory in the UK. Research where no behavioral theory was used was mainly performed in the UK (NL 7\% vs UK 34\%).

Social cognitive theories are based on a person's selfefficacy beliefs-people's judgments of their capabilities to organize and execute certain behavior, the importance attached to the behavior, and its impact on how the social environment thinks about that behavior. The social cognitive theories suggest that the intention for a particular behavior is the best predictor of a person's behavior (eg, register their preference in the DR) [9]. Noncognitive theories are based on beliefs or concerns that are associated with affect or emotions and seem to be stronger predictors of registration than predictors based on cognitive-based theories [10].

We identified 8 broad categories as associated barriers that apparently influenced residents not to sign the DR.
These were: religion; medical mistrust, anxiety, and affective emotions; lack of information about donation; time to mourn/regular funeral; physical integrity; ignorance about how to register in the DR; own benefit; and social status. Many of the articles reported several or multiple factors and therefore appear under several headings. We present the barriers toward considering enrollment in the DR identified with a $P$ value of $\leq .01$. We also put forward factors for which no statistical results were reported, but which the authors considered worth presenting. The associated barriers identified are summarized in a scheme and presented in Appendix 1.

\section{Religion}

Six studies were retrospectively collected via surveys among residents in UK and NL in an attempt to identify factors associated with religion relevant to enrollment in the DR. Respondents with a Protestant background were less inclined to return their registration form, had less self-efficacy, and experienced more social positive outcome expectations than students with no religion [R11]. Respondents reporting religions other than Roman Catholic or Protestant showed less registration intention than students with no religion (atheist) [R10,R11]. The highest registration rate was among students with no religion, followed by Protestants and Catholics, with Jews and Muslims having the lowest rate. Muslims and Jewish respondents had less knowledge about donation, less selfefficacy, and experienced more negative outcome expectations than participants with no religion [R10]. The majority of Muslim respondents thought that donation was not compatible with their faith and were not aware of the fatwa issued by 


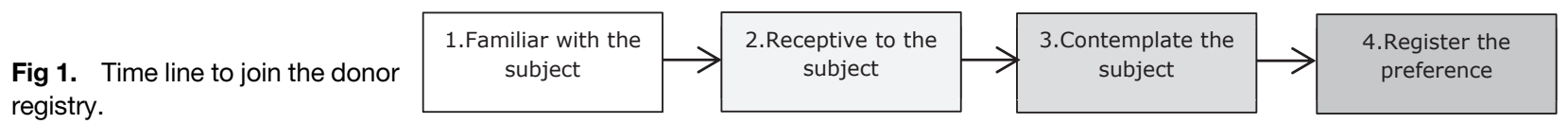
registry.

the Muslim law Council UK that allows organ donation $[\mathrm{R} 1, \mathrm{R} 2]$. The majority of respondents with an Indo-Asian background were not registered [R2].

\section{Medical Mistrust, Anxiety, and Affective Emotions}

Feelings of anxiety and the process of registering as an organ donor were associated with contemplating death $[\mathrm{R} 7, \mathrm{R} 8]$. Registration was shown to be negatively influenced if participants held a higher level of medical distrust, such as misappropriation or misuse of organs [R7]. The more feelings of medical mistrust ${ }^{1}$ or affective emotions, eg "Jinx" or "Ick", the less chance there was that participants were registered as an organ donor [R8,R15].

\section{Lack of Information About Donation}

We identified 5 papers that included shortage of information about donation as a reason for not registering in the DR. Awareness of organ shortages, knowing someone with a transplant, or a donor in the family are factors positively associated with signing the DR [R1,R5]. Being aware of what eye donation involves, being more knowledgeable of the benefits [R6], and the level of knowledge about organ and tissue donation were positively related to the intention to register as a donor [R13,R14].

\section{Time to Mourn/Regular Funeral}

Three papers reported that the most important barriers to registering were that the funeral would be delayed, or that they would not have enough time to say goodbye [R1,R3,R6].

\section{Physical Integrity}

Bodily/physical integrity represents the belief in the maintenance of bodily integrity after death. There were 7 papers associated with physical integrity, the idea of mutilation of the body [R1,R2,R4,R6,R8,R15], or the general objection to donating eyes for tissue after death [R6], and when these ideas were present, people were less likely to register.

\section{Ignorance About How to Register in the DR}

Two papers indicated that more information was needed on how to register in the DR. Factors associated were not

\footnotetext{
${ }^{1}$ Medical mistrust is viewed as the common fear that doctors may hasten the death of seriously ill patients to harvest their organs.

2 Jinx factor are related to fears and superstitions about the misfortune that would result if a person registered as an organ donor or actually donated his or her organs.

${ }^{3}$ Ick factor indicates greater feelings of disgust at the idea of organ donation.
}

knowing how to register $[\mathrm{R} 2, \mathrm{R} 4, \mathrm{R} 6]$ or participants thinking it was difficult to complete a registration form [R9].

\section{Own Benefit}

Perceived benefit is one of the 6 aspects of the Health Beliefs Model and posits the likelihood that a person will take health-related action depending on rational core beliefs. People imagine perceived benefits, eg, continuing survival of their loved one's organ after death through the recipient(s); the stronger this perception, the higher the likelihood that they will consent [R8].

\section{Social Status}

More strongly endorsing social conformity and less endorsing of hedonism are positively related to intention to register [R14]. People valuing social conformity above hedonism are more likely to register.

\section{DISCUSSION}

The main barriers to enrollment in the DR were religion, anxiety and medical mistrust, lack of information about donation, time to mourn/regular funeral, physical integrity, ignorance about how to register in the DR, own benefit, and social status. The studies were based on social cognitive and noncognitive theories, or there was no theory used.

Noncognitive theories are based on beliefs or concerns that are associated with affect or emotions and seemed to be stronger predictors of registration than predictors based on cognitive-based theories.

The more that emotional affective barriers are felt (eg, anxiety, bodily integrity, and medical mistrust) the less chance residents will register as an organ donor. Respondents with a more strict religious background or non-Western beliefs are less willing to register in the DR than atheists.

Based on the research conducted both in UK and NL, the behavioral differences appear to be small when it comes to the barriers to registering in the DR. To meet the goal of the Dutch donation act to obtain more consenting donors for transplantation purposes, much will depend on the response and the decision of the 18 -year-olds, who receive a registration form in the year they reach that age. This possibly explains the considerable amount of research conducted among students in NL. In UK, there is no age limit on registering and there is not a yearly campaign such as the one in NL aimed at young adults at the age of 18 years. In UK there are several new campaigns every year, some of them targeting younger people.

\section{Medical Mistrust, Anxiety, and Effective Emotions}

Affective attitudes seem to influence whether a person decides to register as a postmortem organ donor [10]. These 


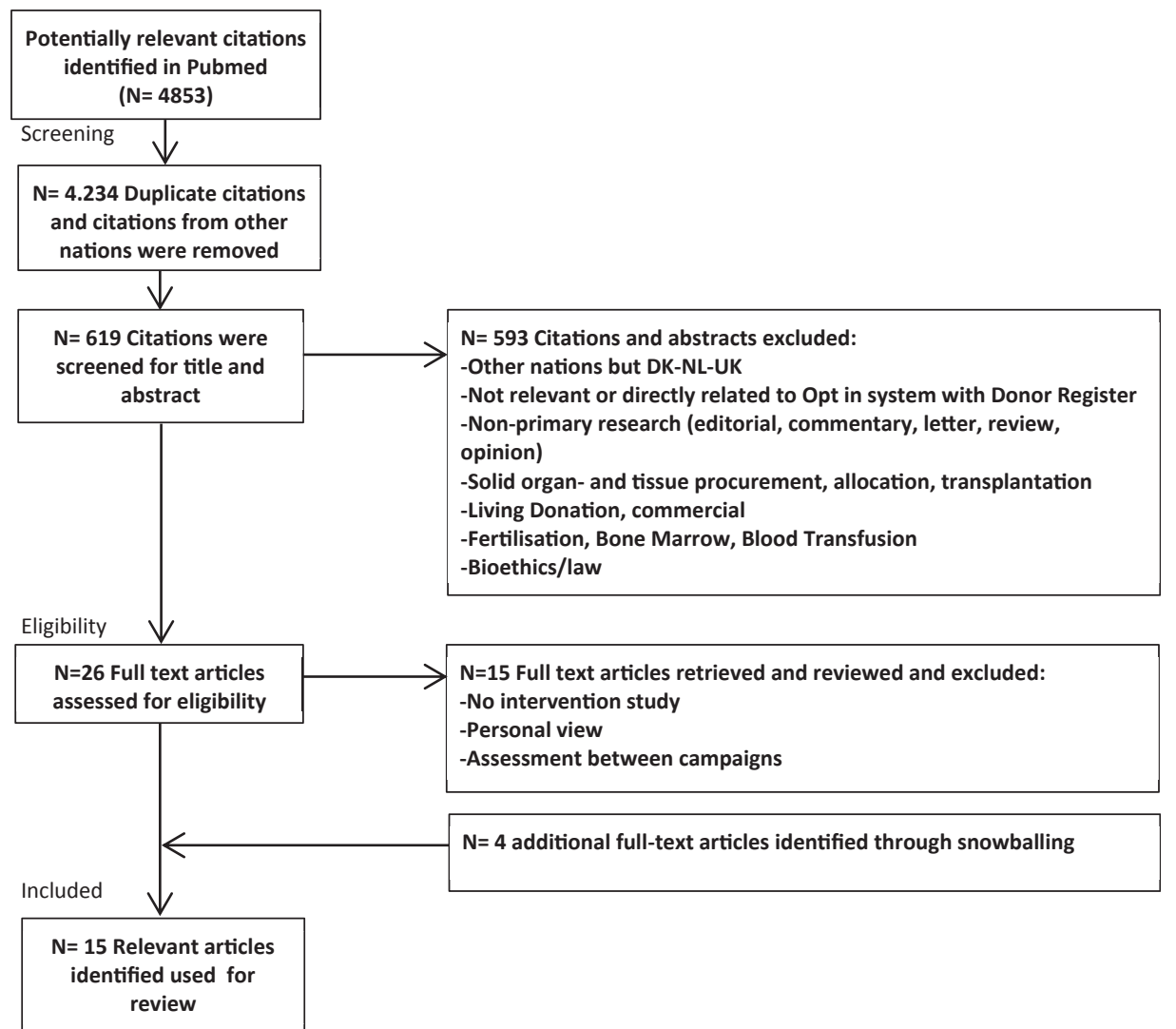

Fig 2. Result of the screening process. affective attitudes, eg, medical mistrust, "ick" factor, "jinx" factor, and bodily integrity, can be defined as beliefs or concerns that are associated with affect or emotions [11]. People who are not registered as organ donors are more likely to feel negative affective attitudes and are less likely to recognize the benefits of donation. In the context of medical mistrust, people may think that physicians will remove them earlier from mechanical life-sustaining support in a potential donor situation. The common fear is that doctors may hasten death of seriously ill patients to harvest their organs [12-14]. This perception could be reduced with correct information about the process of donation $[15,16]$. Information should also include the fact that physicians involved in postmortem organ and tissue donation are strictly separated from the transplantation side. The Euro Transplant International Foundation facilitates allocation and cross-border exchange of organs from deceased donors. Allocation of organs and tissue is based on medical and ethical grounds [17]. Anxiety and medical mistrust could be diminished by proper and clear information about the donor procedure.

Some religions advocate (eg, Catholic), allow (eg, Islam), or forbid (eg, Shinto) donation. Of the 15 included articles, $6(40 \%)$ were apparently associated with Western and nonWestern religions. Research performed in UK reported influential factors mainly related to Islam or Asian (eg, Hindu, Sikh) religions and research performed in NL was mainly associated with the Roman Catholic or Protestant religion.

In NL, research shows that church or mosque visitors are less represented in the DR than nonbelievers [18]. Strict religious believers are more reluctant to register in the DR. One of the reasons, for example, is that Muslims struggle with the question whether their faith is compatible with organ donation. Bodily/physical integrity represents the belief in the need to maintain bodily integrity after death or face serious afterlife consequences. The issue of bodily integrity appears to be an important barrier, but in general no religion is against organ donation. On the contrary, all the major religions have issued statements of outright support for organ donation [19]. In general, if the need and the suffering of a patient are high and transplantation with an acceptable risk and chance of success is possible, organ donation may take place. Organ donation is recommended as long as respect for the body is based on force majeure or "emergency breaks law" [19]. This means that the needs of the living outweigh the needs of the dead and must be seriously taken into consideration. To overcome religious barriers for those people who think that their religion does not allow organ donation, religious faith leaders could become more involved. Some research among ethnic minorities shows positive signs $[13,20,21]$. To Muslims, the holy month of Ramadan seems to be an opportunity to advocate the concept of organ donation and registration in 
the DR [22]. To increase registration, the spiritual or faith leaders have an important role in providing honest and reliable information to those who are seeking knowledge about this topic [23]. Spiritual or faith leaders sometimes spread ideas that no longer represent the up-to-date standpoints of their religion regarding donation. It is important that they inform themselves of contemporary guidelines and stimulate the latent awareness of the need for organs and tissues. They could spread targeted information on success and limitations of tissue and organ transplantation, forms regarding donation and its procedure, and information about registration opportunities in the DR [24,25]. To increase donor registration rates, it is better to involve spiritual leaders in discussions from the start.

Perceived benefit involves the aspect of reciprocity, the basis of gift exchange. On the basis of gift exchange, there are dimensions of reciprocity; at one extreme, there is a pure gift, for which nothing is expected in return, and at the other extreme is the maximization of one's own benefit [26]. The Dutch Organ and Tissue Act and its DR assumes that organ donation is a pure gift based on altruism and anonymity. However, organ donation does not differ from the idea of benevolence in blood donation with both the donor and recipient gaining from the transaction. In comparing the individual motivation of blood donors and organ donors, it is clear that in both situations, discussing the matter with family and friends increases the likelihood of the intention to register as donor. Mutual social support seems to be an important factor and to make the decision people also need a positive attitude and have confidence in their ability to carry out the donor registration process, and to cope with the consequences of this decision [27,28]. Research shows that discussing the topic within the family supports registration [29-33]. Besides the appeal to altruism, there are proponents of using incentives to encourage people to enroll in the DR. Despite the natural assumption that personal incentives are likely to appeal to people, research indicates that many do not favor them, especially when it comes to financial incentives [34]. As for blood donation, research studies have shown that financial incentives have a discouraging effect on social behaviors and will reduce the number of blood donors in the long term [34,35]. Ultimately, any incentive intervention must be based on the best evidence and a careful evaluation of long-term consequences [34]. The effect of the incentive depends on people's intention to register or object. Although research has shown that respondents are motivated to donate altruistically, they would also accept reciprocity for organs once consent was given. Payment for organs was viewed as unfavorable; however the respondents found a contribution toward funeral expenses to be acceptable [31] and an indirect incentive, such as a contribution to the burial costs (eg, $\$ 1,500)$, is therefore likely to be effective [34,36,37].

The result of a nominal group study revealed factors influencing people's decision to register for organ donation. Although that study was performed in Australia, the information presented can give us clues. The top 5 factors from that study were saving lives, own decision to donate, family opinions, benefit to recipients, and the process of organ donation [25]. In addition, some people are reluctant to register because they thought donation would delay the funeral. Other barriers revealed were also of a practical nature, eg, the barriers of how to register and access the DR. Research on blood donors showed that easy access to the registry could help [28]. Since 2007, the Dutch DR offers the use of an online donor form and thus makes enrollment more accessible. Besides this, the amount of information and knowledge about donation are important factors and are positively related to the intent to register $[13,23,30,38,39]$.

This review, based on articles from UK and NL, revealed the complexity of individuals' behavior toward registration into the DR. Insight into the barriers to registering will help to develop policies and supply general and targeted information in order to increase the number of registrations in the DR.

\section{LIMITATIONS AND STRENGTHS}

A limitation of the study is that we measured self-reported intention and willingness to donate instead of actual behavior. Information on actual registration behavior is not available, because the data from the Dutch DR are protected by privacy legislation. Most of the research focused on students, the general public, or ethnic minorities in a geographically defined region or country. There were no results on a country as a whole. The strength of the present review is that it gives insights into barriers to registering in 2 Western nations with similar DRs. Covering a period of 15 years, the included studies were mostly theory based. It is well established that behavioral intentions are a strong and consistent determinant of actual (registration) behavior [9].

\section{CONCLUSION}

The DR gives people the opportunity to express their donor wishes. This gives clarity and certainty at time of death to next of kin and physicians involved in the request for donation.

The outcome of this review suggests that the barriers to enrolment in the DR are mainly based on religion, medical mistrust and anxiety/affective attitude, lack of information about donation, physical integrity, own benefit, and social status. Some barriers might be modifiable by giving proper and clear information to potential donors. However, not all barriers are easily modifiable owing to affective attitudes. This review revealed engagement points that could help to develop policies to increase the number of registrations in the DR.

\section{REFERENCES}

[1] Dutch Organ and Tissue Act. Available at: http://wetten. overheid.nl/BWBR0008066/2016-08-01. 
[2] Dutch National Donor Registry. Available at: https://www. donorregister.nl/.

[3] van Netten AR. Donor Registration Campaign: Ministry of Public Health involves personal request to 12.2 million Dutch citizens $\geq 18$ years. Transplant Proc 2000;32:123.

[4] Dutch Transplant Foundation. Annual report 2016. Available at: http://www.transplantatiestichting.nl/bestel-en-download/ntsjaarverslag-2016.

[5] European Commission. Organ donation and transplantation. Eurobarometer 2010. Available at: http://ec.europa.eu/commfront office/publicopinion/archives/ebs/ebs 333a en.pdf.

[6] European Commission. Europeans and organ donation. Special Eurobarometer 2007. Available at: http://ec.europa.eu/ commfrontoffice/publicopinion/archives/ebs/ebs_272d en.pdf.

[7] de Groot J, Vernooij-Dassen M, Hoedemaekers C, et al. Decision making by relatives about brain death organ donation: an integrative review. Transplantation 2012;27(93):1196-211.

[8] Rosenblum AM, Ho Ting Li A, Roels L, et al. Worldwide variability in deceased organ donation registries. Transpl Int 2012;901:8011.

[9] Horton RL, Horton PJ. Knowledge regarding organ donation: identifying and overcoming barriers to organ donation. Soc Sci Med 1990:31:791-800.

[10] Morgan SE, Stephenson MT, Harissin TR, et al. Facts versus feelings. J Health Psychol 2008;13:644-58.

[11] O'Caroll RE, Foster C, McGeechan G, et al. The ick factor, anticipated regret, and willingness to become an organ donor. Health Psychol 2011;30:236-45.

[12] Newton JD. How does the general public view posthumous organ donation? A meta-synthesis of the qualitative literature BMC Public Health 2011;11:791.

[13] Morgan M, Nayblin M, Jones R. Ethnicity and registration as a kidney donor: the significance of identity and belonging. Soc Sci Med 2008;66:147-58.

[14] Quick Bl, LaVoiie NR, Scott AM, et al. Perceptions about organ donation among African American, Hispanic and white high school students. Qual Health Res 2012;22:921-33.

[15] Dutch Transplant Foundation. Dutch Protocol post mortal organ and tissue donation. Version 9.8. January 2018. Braindeath. Available at: https://www.transplantatiestichting.nl/sites/default/ files/modelprotocol postmortale orgaan- en weefseldonatie.pdf.

[16] Health Council of the Netherlands. Determining death in post mortal organ donation. The Hague: I-297/04/PE/db/021-A; June 10, 2015.

[17] Eurotransplant International Foundation. Code of conduct 2015 and Eurotransplant's aims. Available at: https://www. eurotransplant.org.

[18] Peeters F, Smeets H. Organ donation and social cohesion 2015. Available at: https://www.cbs.nl/nl-nl/publicatie/2015/45/ sociale-samenhang-2015-wat-ons-bindt-en-verdeelt.

[19] Sanders J. Life by giving: religious and philosophical views on organ and tissue donation (Leven door geven: religieuze en levensbeschouwelijke standpunten over orgaan- en weefseldonatie). Nijmegen, The Netherlands: Meinema, Zoetermeer en Kaski; 2003.

[20] Andrews AM, Zhang N, Chapman R, et al. Increasing donor designation through black churches: results of a randomized trial. Prog Transplant 2011;92:1108-14.

[21] Sharif A, Jawad H, Nightingale P, et al. Quantitative survey of western Muslim attitudes to solid organ donation. Transplantation 2011;92:1108-14.

[22] Najafizadeh K, Ghorbani F, Hamidinia S, et al. Holy month of Ramadan and increase in organ donation willingness. Saudi J Kidney Dis Transpl 2010;21:443-6.

[23] Rady MY, Verheyde JL. Campaigning for organ donation at Mosques Hec forum. 2016;28:193-204.

[24] Dutch Transplant Foundation, information to the public. To be a donor/Why become a donor/Religion and donation]. Available at: https://www.transplantatiestichting.nl/donor-worden/waaromdonor-worden/geloof-en-donatie.
[25] Irving MJ, Jan S, Tong A, et al. What factors influence people's decision to register for organ donation? The result of a nominal group study. Transpl Int 2014 Jun;27(6):617-24.

[26] Komter AE. The gift: an interdisciplinary perspective. Amsterdam: Amsterdam University Press; 1996. ISBN 9053561730.

[27] Hyde MK, Simon R, Knowles SR, White KM. Donating blood and organs: using an extended theory of planned behaviour perspective to identify similarities and differences in individual motivations to donate. Health Educ Res 2013;28:1092-114.

[28] Godin G, Sheeran P, Conner M, et al. Factors explaining the intention to give blood among general population. Vox Sanguinis: Blackwell Publishing ltd; 2005;89, 140-149.

[29] Park HS, Smith SW, Yun D. Ethnic differences in intention to enroll in a state organ donor registry and intentions to talk with family about organ donation. Health Commun 2009;24:647-59.

[30] Feeley TH, Anker AE, Watkins B, et al. A peer to peer campaign to promote organ donation among racially diverse college students in New York City. J Natl Med Assoc 2009;101:1154-62.

[31] Sharp C, Randhawa G. Organ donation as an altruistic gift: Incentives and reciprocity in deceased organ donation from UK Polish migrant perspective. Ann Transplant 2014;19:23-31.

[32] Hyde MK, White KM. Communication prompts donation; exploring the beliefs underlying registration and discussion of the organ donation decision. Br J Health Psychol 2008;14930:423-35.

[33] Vincent A, Logan L. Consent for organ donation. Br J Anesth 2012;108(Suppl 1):i80-7.

[34] Schold JD, Segev DL. Increasing the pool of deceased organs for kidney transplantation. Nat Rev Nephrol 2012;8:325-32.

[35] Abolghasemi H, Hosseini-Divkalaya NS, Seighali F. Blood donor incentives: a step forward or backward. Asian J Transfus Sci 2010;4:9-13.

[36] Maarse H, Istamo T. The influence of decision systems on the availability of donor organs; an international comparison. Research report, Dutch Government of Health. Maastricht University; 2008. Available at: http://docplayer.nl/amp/26959491De-invloed-van-beslissystemen-op-de-beschikbaarheid-van-donor organen-een-internationale-vergelijking.html.

[37] Jasper JD, Nickerson CA, Ubel PA, Asch DA. Altruism, incentives and organ donation: attitudes of the transplant community. Med Care 2004;42:378-86.

[38] Deedat S, Kenten C, Morgan M. What are effective approaches to increasing rates of organ donor registration among ethnic minority population: a systemic review. BMJ Open 2013;3: e003453.

[39] Li AHT, Rosenblum AM, Nevis IF, et al. Adolescent classroom education on knowledge and attitudes about deceased organ donation: a systemic review. Pediatr Transplant 2013;17: $119-28$.

\section{ARTICLES INCLUDED IN THIS REVIEW}

[R1] Aslam A, Hameed W. UK Muslim graduates need more information about organ donation and transplant. Eur Soc Organ Transplant 2008;21:92-3.

[R2] Beddi KK, Hakeem R, Dave R, Lewington A, Sanfey H, Ahmad N. Survey of the knowledge, perception, and attitude of medical student at the University of Leeds toward organ donation and transplantation. Transplant Proc 2015;47:247-60.

[R3] Figueroa CA, Mesfum ET, Acton NT, Kunst AE. Medical students' knowledge and attitudes toward organ donation: results of a Dutch survey. Transplant Proc 2013;45:2093-7.

[R4] Hakeem AR, Dave R, Prasad KR, Menon KV, Lewington A, Fernando B, et al. An imperative need to change organ donation and transplant curriculum results of a nationwide United Kingdom junior doctor survey. Transplantation 2015;99: 771-85.

[R5] Karim A, Jandu S, Sharif A. A survey of South Asian attitudes to organ donation in the United Kingdom. Clin Transplant $2013 ; 27: 757-63$. 
[R6] McGlade D, McClenahan C, Pierscionek B. Attitudes underlying corneal donation in a group of trainee allied health professionals. PLoS One 2012;7:e53538.

[R7] McGlade D, McClenahan C, Pierscionek B. Pro-donation behaviours of nursing students from the four countries of the UK. PloS One 2014;10:e91405.

[R8] O'Caroll RE, Foster C, McGeechan G, Sandford K. The ick factor, anticipated regret, and willingness to become an organ donor. Health Psychol 2011;30:236-45.

[R9] Reubsaet A, Brug J, de Vet E, van den Borne B. The effect of practising registration of organ donation preference on selfefficiency and registration intention: an enactive mastery experience. Psychol Health 2003;18:585-94.

[R10] Reubsaet A, Brug J, Nijkamp MD, Candel MJJM, van Hooff JP, van den Borne HW. The impact of an organ donation registration information program for high school students in the Netherlands. Soc Sci Med 2005;60:1479-86.
[R11] Reubsaet A, Brug J, van den Borne B, van Hoof H. Predictors of organ donation registration among Dutch adolescents. Transplantation 2001;72:51-6.

[R12] Reubsaet A, van den Borne B, Brug J, Pruyn J, van Hoof H. Determinants of the intention of Dutch adolescents to register as organ donors. Soc Sci Med 2001;53:383-92.

[R13] Reubsaet A, Brug J, Kistelaar J, van Hoof JP, van den Borne HW. The impact and evaluation of two school based interventions on intention to register an organ donor preference. Health Educ Res 2004;19:447-56.

[R14] Ryckman RM, Gold JA, Reubsaet A, van den Borne B. Value priorities and intention to register for posthumous organ donation in Dutch adolescents. J Soc Psychol 2009;149:213-28.

[R15] Shepherd L, O'Carrol R. Do affective attitudes predict organ donor registration? A prospective study. J Health Psychol 2014;19:1329-33. 


\begin{tabular}{|c|c|c|c|c|c|c|}
\hline \multirow[b]{2}{*}{ Study } & \multirow[b]{2}{*}{ Study } & \multirow[b]{2}{*}{ Method } & \multirow{2}{*}{$\begin{array}{l}\text { Not registered } \\
\text { in DR, \% (total } n \text { ) }\end{array}$} & \multirow[b]{2}{*}{ Barriers } & \multicolumn{2}{|l|}{ Results } \\
\hline & & & & & $\%$ & $P$ value \\
\hline \multicolumn{7}{|l|}{ Religion } \\
\hline \multirow[t]{2}{*}{ Aslam et al, 2008, UK [R1] } & Convenience sample & $\begin{array}{l}\text { Questionnaire survey among } \\
\text { Muslim graduates with } \\
\text { nonmedical background }\end{array}$ & $86 \%(54)$ & $\begin{array}{l}\text { Religious prohibition, participants } \\
\text { thought donation was not allowed } \\
\text { in Islam }\end{array}$ & $54 \%$ & $\mathrm{n} / \mathrm{a}$ \\
\hline & & & & $\begin{array}{l}\text { Only one-fourth of the graduates } \\
\text { were aware of fatwa issued by } \\
\text { Muslim Law Council UK that } \\
\text { allows organ donation }\end{array}$ & $25 \%$ & $\mathrm{n} / \mathrm{a}$ \\
\hline \multirow[t]{3}{*}{ Beddi et al, 2015, UK [R2] } & Questionnaire & $\begin{array}{l}\text { Survey among medical } \\
\text { students }\end{array}$ & $61.9 \%(216)$ & $\begin{array}{l}\text { More students of Indo-Asian } \\
\text { ethnicity were not registered than } \\
\text { registered. }\end{array}$ & $\mathrm{n} / \mathrm{a}$ & $<.001$ \\
\hline & & & & $\begin{array}{l}\text { Pervious experience in } \\
\text { transplantation; knowledge, } \\
\text { attitudes, and perceptions; atheist } \\
\text { not registered vs registered }\end{array}$ & $\mathrm{n} / \mathrm{a}$ & $<.001$ \\
\hline & & & & $\begin{array}{l}\text { My religion/belief does not allow } \\
\text { organ donation }(n=193)\end{array}$ & $3.1 \%$ & $\mathrm{n} / \mathrm{a}$ \\
\hline \multirow[t]{3}{*}{ Hakeem et al, 2015, UK [R4] } & Cross-sectional & $\begin{array}{l}\text { Survey among } \\
\text { junior doctors }\end{array}$ & $30.2 \%(523)$ & $\begin{array}{l}\text { Junior doctors with atheistic beliefs } \\
\text { are likely to be registered as organ } \\
\text { donor than not registered. }\end{array}$ & $\begin{array}{l}87.9 \% \\
\text { vs } 12.1 \%\end{array}$ & $<.001$ \\
\hline & & & & $\begin{array}{l}\text { Junior doctors with Muslim belief } \\
\text { registered vs not registered. }\end{array}$ & $\begin{array}{l}16.7 \% \\
\text { vs } 83.3 \%\end{array}$ & $<.001$ \\
\hline & & & & $\begin{array}{l}\text { Junior doctors with Hindu belief } \\
\text { registered vs not registered. }\end{array}$ & $42.8 \%$ vs $57.2 \%$ & $<.001$ \\
\hline \multirow[t]{4}{*}{ Karim et al, 2013, UK [R5] } & $\begin{array}{l}\text { Voluntary, both online } \\
\text { and paper-based approach }\end{array}$ & $\begin{array}{l}\text { Two separate surveys } \\
\text { among South Asian } \\
\text { Muslims residing in the UK }\end{array}$ & $86.7 \%(556)$ & $\begin{array}{l}\text { Muslims were less likely than } \\
\text { Hindus or Sikhs to be registered } \\
\text { donors }\end{array}$ & $\begin{array}{c}5.0 \% \text { vs } 40.3 \% \\
\text { vs } 25.8 \%\end{array}$ & $<.001$ \\
\hline & & & & $\begin{array}{l}\text { Asians living with parents were less } \\
\text { likely to agree that organ donation } \\
\text { was compatible with their faith: } \\
\text { living with vs not living with } \\
\text { parents (no statistical difference) }\end{array}$ & $\begin{array}{l}12.0 \% \\
\text { vs } 18.8 \%\end{array}$ & $<.086$ \\
\hline & & & & $\begin{array}{l}\text { Registered organ donor: non- } \\
\text { Muslim vs Muslim }\end{array}$ & $\mathrm{n} / \mathrm{a}$ & $<.001$ \\
\hline & & & & $\begin{array}{l}\text { Registered organ donor: not very } \\
\text { religious vs very religious. }\end{array}$ & $\mathrm{n} / \mathrm{a}$ & $<.001$ \\
\hline Reubsaet et al, 2001, NL [R11] & Cross-sectional & $\begin{array}{l}\text { Survey among Dutch } \\
\text { adolescents }\end{array}$ & $100 \%(937)$ & $\begin{array}{l}\text { Adolescents with a Protestant } \\
\text { background were less inclined to } \\
\text { return their registration form }\end{array}$ & $\mathrm{n} / \mathrm{a}$ & $<.01$ \\
\hline
\end{tabular}




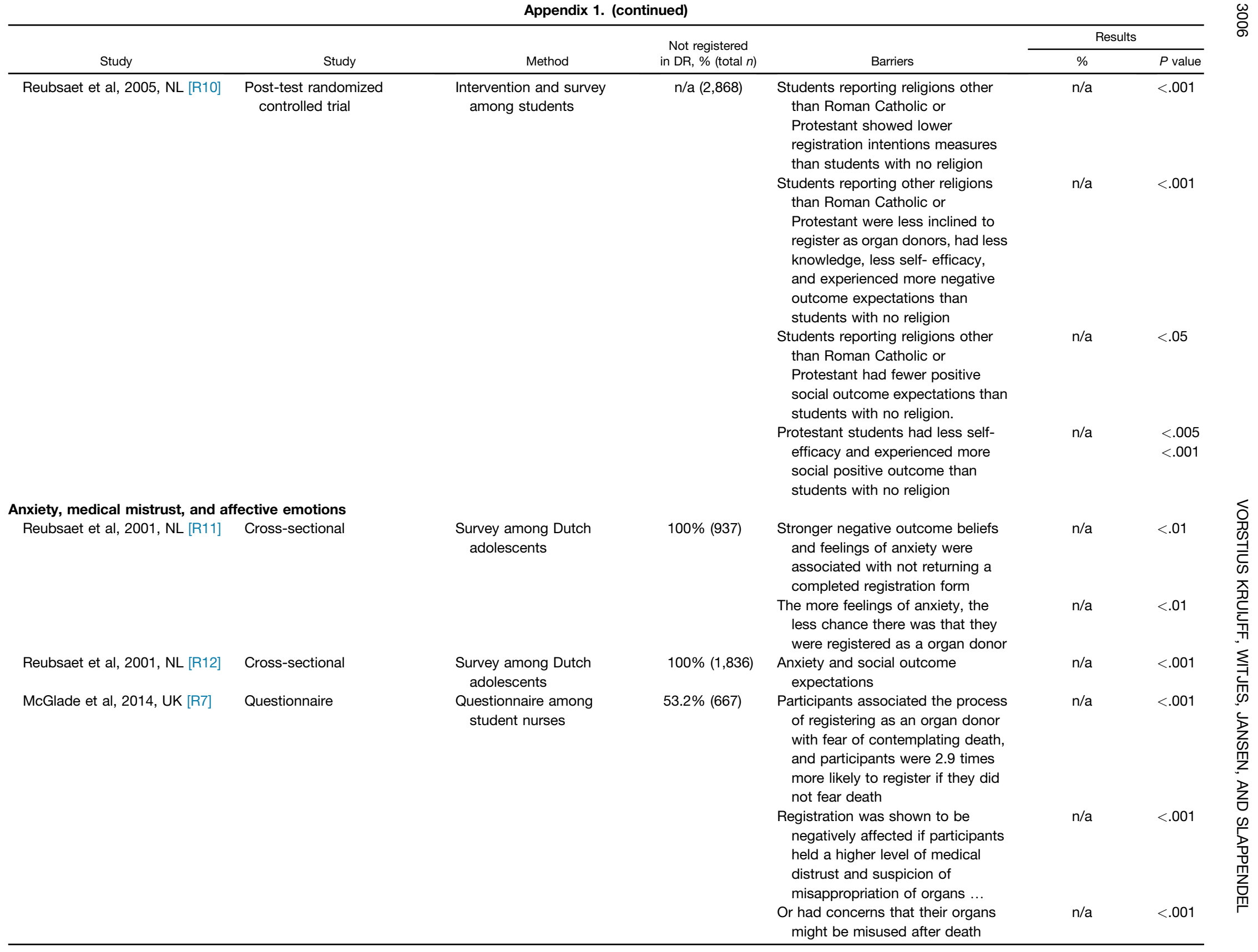


O'Caroll et al, 2011, UK [R8] Experiment

Shepherd et al, 2013, UK [R15] Randomized control

Lack of information about donation

Aslam et al, 2008, UK [R1] Convenience sample

Karim et al, 2013, UK [R5] paper-based approach

McGlade et al, 2012, UK [R6] Questionnaire

Ryckman et al, 2010, NL [R14] Sample

Reubsaet et al, 2004, NL [R13] Random experimental intervention

Time to mourn/regular funeral

Aslam et al, 2008, UK [R1]

Convenience sample

Figueroa et al, 2013, NL [R3]
Voluntary, both online and
Questionnaire of general public

uestionnaire among

undergraduate students

Questionnaire survey based on convenience sample

among Muslim graduates with nonmedical

background

Two separate surveys

among South Asian

Muslims residing in the UK

$86.7 \%(556)$

Self-explanatory

questionnaire among

preregistration nurses

Survey among Dutch adolescents

Self-administered

questionnaire among

students

Questionnaire survey based on convenience sample without a medical

background

Survey among medical students among Muslim graduates

A greater feeling of medical mistrust Jinx factor suggests a feeling that it is bad luck to talk about death or becoming an organ donor

Ick factor indicates a greater feeling of disgust at the idea of organ donation

100\% (150) Jinx factor

Ick factor

Medical mistrust

86\% (54) Lack of information

Awareness versus no

awareness of organ shortages

Know versus do not know

somebody with a transplant

South Asians in the UK felt that organ donation promotion was

very poorly carried out

n/a (92) Being more aware of what eye donation involves

Being more knowledgeable about the benefits of donation

100\% (375) Level of knowledge about organ donation was related positively to the intention to register as organ donor

100\% (186) Participants in the video group with discussion were more likely to be willing to register their organ donation preferences and were more likely to intend to register as a posthumous donor

86\% (54) Participants do not consider organ donation because of delay in funeral

$n / a$ 


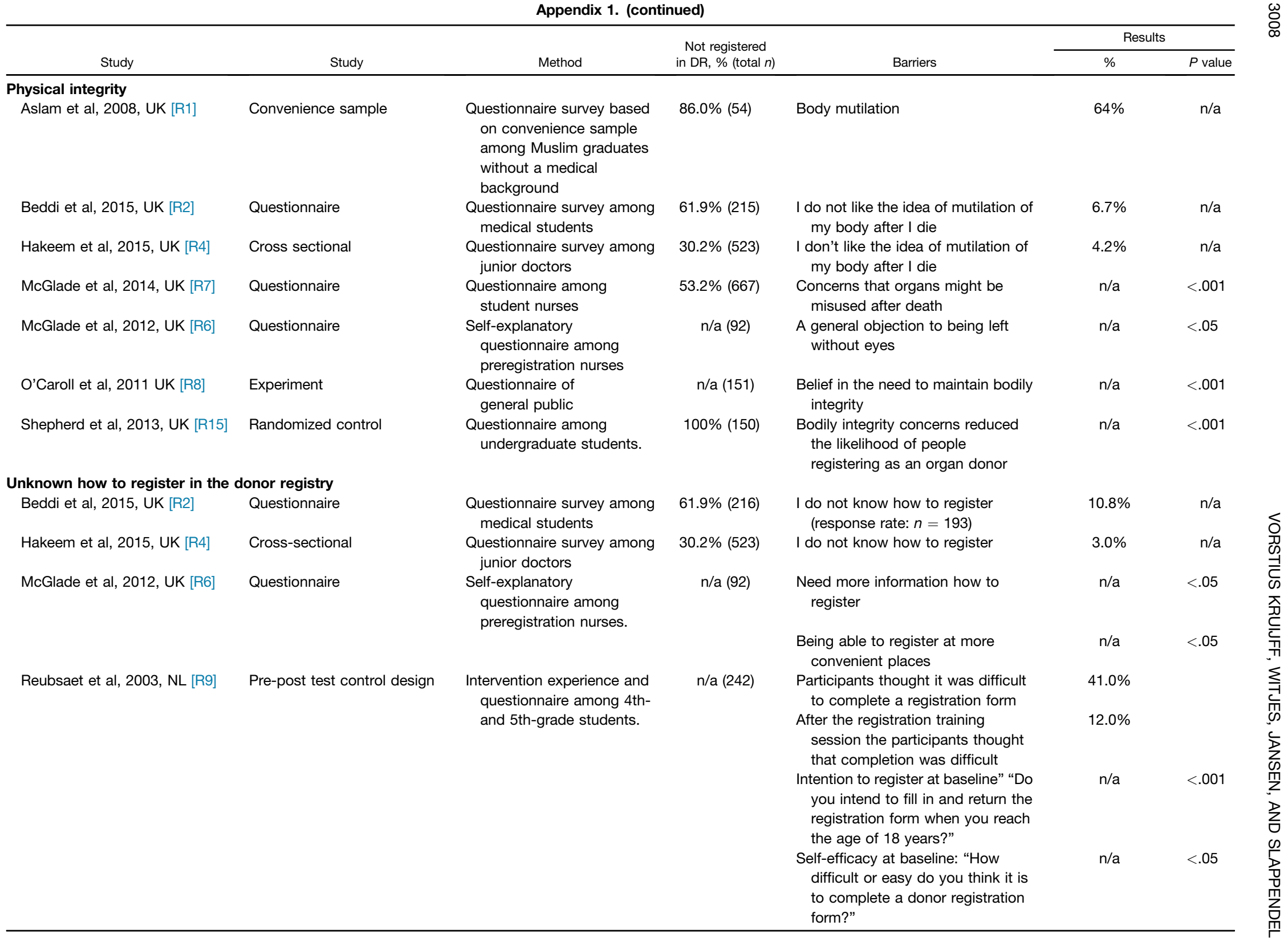


Own benefit

O'Caroll et al, 2011, UK [R8] Experiment

Social status

McGlade et al, 2012, UK [R6] Questionnaire

Reubsaet et al, 2001, NL [R12] Cross-sectional

Ryckman et al, 2010, NL [R14] Sample
Questionnaire of general

public

Self-explanatory

questionnaire among

preregistration nurses

Survey among Dutch

adolescents

Survey among Dutch

adolescents n/a (151) Nondonors perceived less benefit of

being an organ donor

$\mathrm{n} / \mathrm{a}(92)$

Beliefs that underpin the nurses' attitude: cause other people to think I am a better person

$100 \%(1,836) \quad$ Anxiety and social outcome

$100 \%(375)$

Participants who more strongly endorsed social conformity and

less strongly endorsed hedonism

reported that they intended to

register as posthumous organ

donors 